Thabiea: Journal of Natural Science Teaching
Program Studi Tadris Ilmu Pengetahuan Alam
Institut Agama Islam Negeri Kudus
http://journal.stainkudus.ac.id/index.php/Thabiea
$p$-issn: $2580-8974, e-i s s n: 2655-898 x$

\title{
Hubungan antara Nilai Ujian Nasional Fisika dengan Penguasaan Konsep Fisika Dasar pada Mahasiswa Tadris Fisika
}

\author{
Eko Wahyu Nur Sofianto ${ }^{\text {a, }}$ * \\ a Prodi Tadris Fisika, Fakultas Tarbiyah dan Keguruan Universitas Islam Negeri Antasari Banjarmasin \\ ${ }^{1}$ ekowahyu@uin-antasari.ac.id *
}

\begin{tabular}{ll}
\hline Informasi artikel & ABSTRAK \\
\hline Kata kunci: & Penelitian ini bertujuan untuk mengetahui korelasi Nilai Ujian Nasional \\
Nilai ujian nasional akhir & Fisika dengan Penguasaan Konsep Fisika Dasar pada mahasiswa Prodi Tadris \\
fisika; & Fisika Tahun Pelajaran 2017/2018. Data diperoleh dari daftar nilai Ujian \\
Penguasaan konsep fisika; & Nasional Fisika sedangkan penguasaan konsep Fisika dasar diperoleh dari \\
Korelasi. & nilai Ujian Akhir Fisika dasar. Analisis data menggunakan uji korelasi r \\
& dengan nilai signifikansi 0,851. Sehingga memperoleh kesimpulan bahwa \\
& terdapat korelasi yang kuat anatara nilai Ujian Nasional Fisika Dasar di atas \\
& rata-rata dengan kemapuan penguasaan konsep Fisika Dasar.
\end{tabular}

\begin{tabular}{ll}
\hline ABSTRACT \\
\hline $\begin{array}{l}\text { Key word: } \\
\text { Nasional Result Examination } \\
\text { of Physics; }\end{array}$ & $\begin{array}{l}\text { The relationship between the National Examination result of Physics } \\
\text { and Basic Physics Concept Mastery of Pre-service Physics Teachers. This } \\
\text { study aims to determine the result of the National Physics Exam with Mastery } \\
\text { Basic physics concept }\end{array}$ \\
of the Basic Physics Concept for 2017 Physics Academic Year Students. Data \\
Corelation & is obtained from the list of result of the National Physics Exam while \\
& mastering basic Physics concepts from the result of the basic Physics Final \\
& Examination. Data analysis uses a key test with a significance result of 0.851. \\
& The phenomenon of a strong foundation for measuring higher outcomes with \\
the ability to master the Basic Physics concept.
\end{tabular}

Copyright (C) 2019 Institut Agama Islam Negeri Kudus. All Right Reserved

\section{Pendahuluan}

Prodi Tadris Fisika menerima mahasiswa baru tahun ajaran 2017/2018 yang berjumlah 17 orang. Salah satu mata kuliah wajib yang ditempuh mahasiswa prodi Tadris Fisika adalah Fisika Dasar. Fisika dasar adalah mata kuliah yang lengkap karena memuat banyak konsep fisika klasik (Young, 2009). Fisika Dasar memerlukan kemampuan dasar kematangan konsep fisika bagi mahasiswa untuk bisa menguasai konsep dengan baik (Rakbarurung, dkk, 2015).

Fisika Dasar pada kurikulum prodi Tadris Fisika dibagi menjadi dua yaitu Fisika Dasar 1 dan Fisika Dasar 2. Materi Fisika dasar 1 terdiri atas materi fisika klasik. Materi fisika klasik dan merupakan konsep dasar tentang fisika seperti Vector, Hukum Newton, Suhu dan Kalor, Tekanan, Fluida Statis dan Momen Inersia. Sedangkan
Fisika Dasar 2 terdiri atas konsep materi tentang electromagnet, alat optic dan astronomi. Fisika Dasar merupakan konsep yang fundamental dan penting dalam mempelajari Fisika selanjutnya (Hoog \& Zoolman, 2002). Kemampuan berpikir mahasiswa Fisika ditentukan oleh cara mahasiswa menyelesaikan soal konsep Fisika Dasar (Fieldman, 2011).

Penguasaan konsep Fisika Dasar berkaitan dengan penguasaan konsep mahasiswa saat belajar fisika di sekolah (Ingerman \& Booth, 2000). Penguasaan konsep Fisika Dasar sebagai sesuatu yang terkait dengan materi fisika sebelumnya bukan dari salah satu atau konsep fisika yang baru (Ingerman \& Booth, 2000). Hasil penelitian Yuruk, Beeth, \& Andersen, 2009; Shaw, 2012; Stocklmayer, Rayner, \& Gore, 2012; Feldman, 2011; Terzella, et.al., 2008; Portillo-Velez, et.al., 2013 menunjukkan 
bahwa memahami konsep fisika dengan pemikiran konsep yang sederhana. Berbagai upaya telah ditemupuh untuk menyajikan pembelajaran yang meminimalisir kesalahan konsep Fisika (Budhi, 2018).

Pada umumnya mahasiswa baru yang mengambil prodi Fisika di tahun pertama kuliahnya mereka belajar dengan giat untuk bisa beradaptasi dengan materi Fisika Dasar (Ekici, 2016). Karena materi Fisika Dasar ini merupakan materi yang penting dalam melanjutkan materi Fisika yang lainnya. Pada umumnya mahasiswa berhasil menyelsaikan dengan baik mengerjakan soal konsep Fisika di sekolah menengah tetapi kesulitan ketika menyelesaikan persoalan konsep Fisika Dasar (Ekici, 2016). Perubahan dan pola mengajar ketika belajar Fisika Dasar menjadi kesulitan tersendiri mahasiswa untuk belajar Fisika (Ekici, 2016).

Mahasiswa Prodi Tadris Fisika berasal dari wilayah regional Kalimantan Selatan. Mahasiswa Prodi Tadris Fisika telah melaksanakan Ujian Nasional Fisika sebelum mereka dinyatakan lulus SMA/MA. Mahasiswa Tadris Fisika sebagian besar masih berupaya adaptasi dengan materi Fisika Dasar yang dipelajari ketika masuk menjadi Mahasiswa Prodi Tadris Fisika. Mahasiswa Prodi Tadris Fisika mempelajari materi Fisika Dasar dengan memahami konten dan suasana pembelajaran Fisika Dasar. Mahasiswa Prodi Tadris Fisika Dasar mempunyai bekal yang cukup untuk kuliah di Prodi Tadris Fisika karena mereka telah lulus dari UMPTKIN (Ujian Masuk Perguruan Tinggi Keagamaan Negeri). Sehingga hal itu cukup sebagai indikator untuk mengukur kemampuan mereka dalam belajar Fisika Dasar.

Ada berbagai upaya untuk mempelajari Fisika Dasar dengan cara yang lebih menarik dan efisen. Mempelajari Fisika Dasar juga dipengaruhi oleh bagaiaman minat dan motivasi mereka belajar Fisika Dasar. Tujuan penelitian adalah untuk menyelidiki bagaimana hubungan antara nilai Ujian Nasional Fisika dengan penguasaan konsep
Fisika Dasar. Penelitian ini juga bertujuan untuk menyelidiki apakah ada hubungan antara hasil belajar Fisika ketika di sekolah juga berpengaruh terhadap belajar Fisika dasar.

Mahasiswa yang belajar Fisika Dasar juga memiliki anggapan bahwa dalam belajar dibantu oleh seorang Dosen yang membantu mereka bealajar Fisika dengan mudah dan menyenangkan. Pendapat ini juga didukung oleh Alptekin dkk (2009) bahwa peran seorang guru memeiliki pengaruh untuk belajar Fisika secara mudah dan menyenangkan. Seorang dosen memiliki pengaruh kepada mahasiswa dengan cara mengajar dan memberikan konsep dengan baik dan benar sehingga mahasiswa termotivasi dalam belajar Fisika Dasar. Materi Fisika Dasar dianggap sebagai modal dasar untuk menjadi seorang guru fisika dengan baik. Sehingga cara mengajar dosen Fisika juga menentukan kemampuan mahasiswa untuk belajar fisika dengan baik dan benar.

Pada penelitian ini materi yang diambil adalah materi Fisika Dasar 1 dengan konsep yang berkaitan dengan besaran pengukuran, vektor, Hukum Newton, gerak dan konsep usaha dan energi. Pada penelitian ditampilkan beberapa soal yang dapat diselesaikan dengan baik dan jga beberapa soal yang dapat diselesaikan dari beberapa mahasiswa. Soal Fisika Dasar dianalisis kemudian mahasiswa diberikan pertanyaan pada tahap konsep yang belum paham. Sehingga dapat memberikan umpan balik dan masukan Dosen Fisika Dasar untuk belajar selanjutnya.

\section{Metode}

Penelitian ini merupakan penelitian korelasi, karena penelitian ini bertujuan untuk menemukan ada tidaknya hubungan antara nilai Ujian Nasional Fisika dengan Penguasaan Konsep Fisika Dasar pada mahasiswa angkatan 2017 Prodi Tadris Fisika Universitas Islam Negeri Antasari Banjarmasin. Menurut Sukardi (2009: 166) penelitian korelasi adalah suatu penelitian yang melibatkan tindakan pengumpulan data 
guna menentukan, apakah ada hubungan dan tingkat hubungan antara dua variabel atau lebih. Penelitian ini dilakukan dengan mengambil nilai mahasiswa yang memilih Ujian Nasional Fisika pada tahap Ujian Nasional. Dari 17 orang mahasiswa Prodi Tadris Fisika yang mengambil Mata Ujian Nasional Fisika Dasar sebanyak 13 orang.

Variabel dalam penelitian ini meliputi satu variabel bebas, yaitu Nilai Ujian Nasional Fisika (X), serta variabel terikat yaitu penguasaan konsep Fisika Dasar (Y). Berikut ini adalah skema hubungan variabel $\mathrm{X}$ dengan variabel $\mathrm{Y}$. Populasi dalam penelitian ini adalah seluruh mahasiswa yang mengikuti Fisika Dasar dengan mengambil Ujian Nasional Fisika. Teknik pengambilan data menggunakan tes UTS nilai Fisika Dasar 1. Analisis data menggunakan uji pearson product moment pada hasil nilai Fisika Dasar 1 dan Nilai Ujian Nasional Fisika. Sebelum dilakukan uji tersebut, data diuji dengan uji prasyarat analisis yaitu uji lineritas dan uji normalitas. Untuk mengetahui korelasi dapat diketahui berdasarkan nilai $\mathrm{r}$ hasil analisi korelasi. Selanjutnya, besar nilai $r$ dapat diinterpretasikan pada tabel korelasi berikut: Tabel 1. Interpretasi Terhadap Nilai r Hasil Analisi Korelasi

\begin{tabular}{cl}
\hline Interval Nilai r & \multicolumn{1}{c}{ Interpretasi } \\
\hline $0,001-0,200$ & Korelasi sangat lemah \\
\hline $0,201-0,400$ & Korelasi lemah \\
\hline $0,401-0,600$ & Korelasi cukup kuat \\
\hline $0,601-0,800$ & Korelasi kuat \\
\hline $0,801-1,000$ & Korelasi sangat kuat \\
\hline
\end{tabular}

\section{Hasil dan pembahasan}

Hasil dari penelitian ini mendapatkan nilai Fisika Dasar semester ganjil 2017/2018 yang juga menempuh Ujian Nasional Fisika sejumlah 13 orang. Dalam tabel disajikan Nilai Ujian Nasional Fisika dan Nilai Fisika Dasar 1 sebagai berikut:
Tabel 2. Hasil Nilai UTS Fisika Dasar 1 dan Nilai Ujian Nasional Fisika

\begin{tabular}{ccc}
\hline Responden & $\begin{array}{c}\text { Nilai Fisika } \\
\text { Dasar } \mathbf{1}\end{array}$ & $\begin{array}{c}\text { Nilai UN } \\
\text { Fisika }\end{array}$ \\
\hline 1 & 88 & 60 \\
\hline 2 & 84 & 57 \\
\hline 3 & 70 & 40 \\
\hline 4 & 45 & 40 \\
\hline 5 & 20 & 40 \\
\hline 6 & 50 & 46 \\
\hline 7 & 77 & 43 \\
\hline 8 & 83 & 57 \\
\hline 9 & 37 & 48 \\
\hline 10 & 21 & 38 \\
\hline 11 & 78 & 50 \\
\hline 12 & 78 & 50 \\
\hline 13 & 30 & 40 \\
\hline 14 & 50 & 40 \\
\hline $\begin{array}{c}\text { Rata-rata } \\
\text { nilai }\end{array}$ & $\mathbf{5 7}$ & $\mathbf{4 6}$ \\
\hline
\end{tabular}

Dari hasil uji korelasi menggunakan SPSS mendapatkan hasil uji korelasi yang dapat dilihat pada tabel 3 sebagai berikut:

Tabel 3. Ringkasan Uji Korelasi

\begin{tabular}{ccc}
\hline $\mathbf{N}$ & $\begin{array}{c}\text { Corelation } \\
\text { Coefficient }\end{array}$ & Keterangan \\
\hline 14 & 0,851 & $\begin{array}{c}\text { Korelasi sangat } \\
\text { kuat }\end{array}$ \\
\hline
\end{tabular}

Dari nilai Fisika Dasar dengan nilai Ujian Nasional Fisika Dasar diketahui korelasi yang sangat kuat dengan nilai $\mathrm{r}=$ 0,851 . Hasil analisis tersebut menunjukkan bahwa siswa mampu menghubungkan kemampuan awal dengan konsep yang pernah diterima. Hal ini sesuai dengan penelitian Irawati (2014) bahwa siswa dengan kemampuan awal tinggi lebih mampu menghubungkan konsep lama dengan konsep baru dibandingkan dengan siswa yang berkemampuan awal rendah. Hal ini juga didukung oleh penelitian Sofianto (2016) bahwa siswa berkemampuan awal tinggi lebih mampu memperbarui pengetahuan baru yang diperoleh dibandingkan dengan siswa berkemampuan awal rendah. Oleh sebab itu, siswa yang memiliki nilai Ujian Nasional Fisika di atas 
rata-rata yang cukup tinggi dapat menguasai konsep Fisika Dasar 1 dengan baik dan benar.

Hasil penelitian juga menunjukkan bahwa bukan hanya faktor dosen yang membantu penguasaan konsep fisika tetapi kemampuan awal siswa juga menentukan penguasaan konsep fisika. Hal ini juga didukung oleh Ekici (2016) bahwa alasan keberhasilan guru dalam kesusksesan siswa belajar fisika bukan ditentukan dari faktor guru sebagai tutor fisika di kelas. Kemampuan awal mahasiswa prodi Tadris Fisika sudah dibekali dari guru fisika di SMA sehingga mahasiswa memiliki modal dan motivasi yang cukup belajar Fisika Dasar 1. Interaksi antara mahasiswa prodi Tadris Fisika dengan lingkungan juga membawa pengaruh belajar konsep Fisika Dasar 1. Penggunaan konsep Fisika Dasar 1 dalam kehidupan sehari-hari seperti penggunaan katrol, vektor dan lain-lain dalam kehidupan sehari-hari memberikan andil dalam motivasi belajar fisika.

Konsep fisika itu sulit juga menjadi motivasi belajar mahasiswa Tadris Fisika. Motivasi sulit dijadikan sebagai pengakuan diri bahwa individu yang bisa mempelajari fisika adalah individu yang lebih baik juga mempelopori motivasi mahasiswa belajar Fisika Dasar. Hal ini didukung oleh Akadeniz et. al (2000) bahwa interaksi lingkungan membuat motivasi belajar fisika lebih tinggi. Siswa mempunyai anggapan di lingkungan bahwa dengan memahami konsep Fisika Dasar dengan baik maka seseorang dinyatakan dapat menguasai dengan baik ilmu sains yang lainnya yaitu matematika, kimia dan biologi (MEB, 2013). Motivasi belajar mahasiswa Tadris Fisika sangat tinggi ketika mendapat anggapan bahwa individu yang bisa menguasai konsep Fisika Dasar memiliki kemampuan yang baik dalam menguasai ilmu sains yang lainnya.

Salah satu bentul soal fisika dasar yang dapat membuat mahasiswa motivasi belajar menjadi tinggi adalah sebagai berikut:

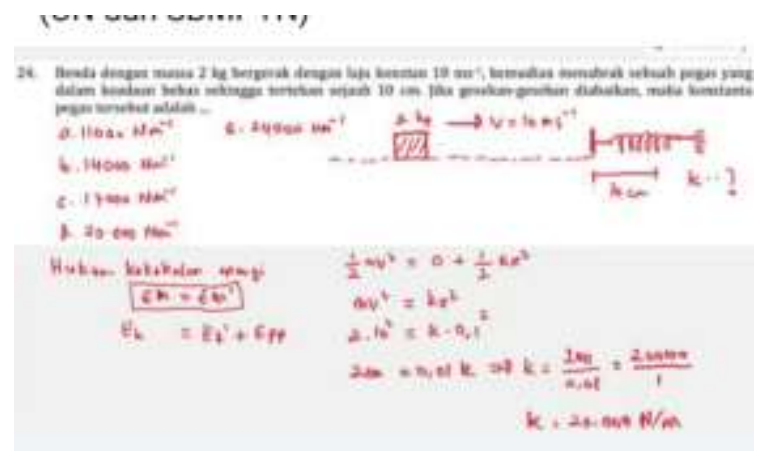

Gambar 1.Hasil analisis jawaban konsep usaha dan energi

Pada gambar 1 mahasiswa diberikan soal tentang konsep energi. Konsep energi ada dalam kehidupan sehari-hari sehinga dengan soal tersebut mahasiswa merasa memliki motivasi untuk belajar fisika. Jawaban mahasiswa yang diberikan juga berkaitan dengan materi konsep fisika SMA yang telah mereka pelajari.

Dari analisis jawaban pada gambar 1 sejmlah 8 mahasiswa yang menjawab dengan benar. Hal ini disebabkan mahasiswa memiliki konsep yang kurang ketika belajar fisika di sekolah. Modal yang mereka miliki untuk menguasai konsep fisika sangat sedikit. Hal ini juga diungkapkan oleh Akdeniz et al (2000) bahwa kebanyakan siswa kesulitan dalam mengerjakan soal konsep fisika karena modal kemampuan mengerjakan fisika yang kurang lengkap. Dari wawancara yang dilakukan peneliti bahwa kebiasaan mengerjakan fisika dengan cara cepat dan mendapatkan hasil yang benar dari sebuah lembaga kursus juga membuat kesulitan untuk belajar Fisika Dasar. Prasetya (2018) menyatakan bahwa penyebab jawaban tak ilmiah juga disebabakan berbagai macam faktor yaitu: intuisi, kurang pemahaman, fragmentasi, dan apresiasi konseptual.

Soal yang mendapat skor penyelesaian tinggi dan mahasiswa dapat menyelesaikan dengan baik adalah soal dengan konsep Hukum Newton. Berikut ananlisis jawaban pada gambar 2: 


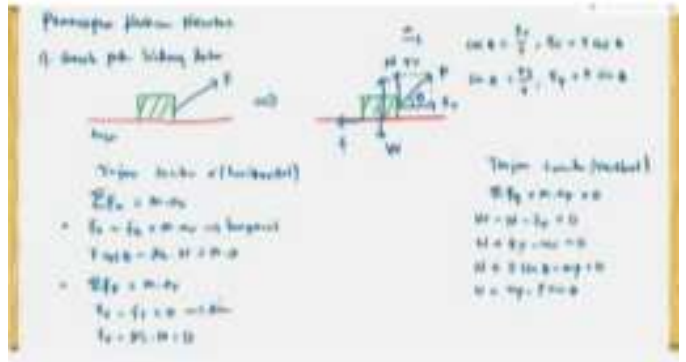

Gambar 2. Analisis jawaban pada soal Hukum Newton

Pada gambar 2 mahasiswa dapat menjawab dengan mudah konsep Hukum Newton. Karena mahasiswa memiliki konsep yang baik pada Hukum Newton kemudian juga dapat diaplikasikan dalam kehidupan sehari-hari. Dosen Fisika Dasar menjelaskan bahwa konsep Hukum Newton begitu banyak dirasakan oleh manusia sehingga mahasiswa menjadi mudah dalam belajar Fisika Dasar. Motivasi mahasiswa belajar Fisika Dasar juga tinggi ketika belajar konsep Fisika Dasar yang mereka jumpai dalam kehidupan sehari-hari. Hal ini dapat dibuktikan dari 14 mahasiswa yang menjawab konsep Hukum Newton dengan benar sebanyak 12 mahasiswa.

Motivasi mahasiswa menjadi tinggi ketika mahasiswa mengerjakan soal Fisika Dasar Hukum Newton. Hal ini disebabkan Hukum Newton adalah konsep kuat yang ada pada semua konsep fisika klasik. Sehingga kebanyakan mahasiswa mendapatkan konsep Hukum Newton dari kelas $\mathrm{X}$ hingga kelas XII SMA/MA berdasarkan aplikasi dari masing-masing materi Fisika. Hal ini berdasarkan pendapat Shaw (2012) bahwa Hukum Newton adalah setengah konsep dari fisika klasik sehingga konsep Hukum Newton menjadi ciri khas fisika klasik dan membantu siswa dalam belajar fisika klasik.

\section{Simpulan}

Dari analisis hasil penelitian mendapatkan data korelasi nilai $\mathrm{r}$ sebesar 0,851 yang menunjukkan korelasi yang kuat antara nilai Fisika Dasar dengan nilai Ujian Nasional Fisika. Hasil ini menunjukkan adanya hubungan antara kemampuan awal yang berupa Nilai Ujian Nasional dengan penguasaan konsep Fisika Dasar 1.

\section{Referensi}

Booth, S: \& Ingerman, Å. (2002). Making sense of Physics in the first year of study. Learning and Instruction, 12, 493-507

Budhi, H.S. (2018). Model Pembelajaran Berbasis Pengalaman untuk Meminimalkan Miskonsepsi Siswa pada Materi Cahaya. Thabiea: Journal of Natural Science Teaching, 1(2), 125-129.

Ekici, Erhan. (2016). "Why Do I Slog Through the Physics?" Understanding High.

Feldman, G. (2011). Dramatic (and Simple!) Demonstrationof Newton's Third Law. Physics Teacher, 49, 103-105.

Hogg, L. K. \& Zollman, D. (2002). Model analysis of the structures of student models: An example with Newton's third law. American Journal of Physics, 70, 766-778.

Irawati, R.K. (2014). Pengaruh Strategi Problem Solving dan Problem Posing serta Kemampuan Awal terhadap Hasil Belajar Siswa pada Materi Kelarutan dan Hasil Kali Kelarutan. Jurnal Pendidikan Sains, Vol. 2. No 4. (184-192).

Portillo-Velez, R. de J., Cruz-Villar, C. A., Rodríguez-Angeles, A., ArteagaPerez, M. A. (2013). Master/Slave.Robotic System for Teaching Motion-Force Manufacturing Tasks. Applied Mechanics and Materials, 307, 84-88.

Prasetyo, D.R. (2018). Tingkat Pemahaman Konsep Siswa pada Materi Momen Gaya. Thabiea: Journal of Natural Science Teaching, 1(2), 79-83.

Prissana Rakbamrunga, Juang Puekkong, Preeyanan Thepnuan. (2015). Students' Understanding Physics Concept of Traction Therapy. Social and Behavioral Sciences 197, 135 139 
School Students' Difficulties in Learning Physics. Journal of Education and Practice, 7, 95-107.

Shaw, M. (2012). I “Saw” Newton's Three Laws. Physics Teacher, 50, 480-481.

Sofianto, W.W.N. (2016). Pengaruh Balikan Formatif Terintegrasi Strategi Pembelajaran Diagram Vee dan Kemampuan Awaal Terhadap Penguasaan Konsep Siswa. Jurnal Pendidikan Fisika, Vol. 12. No 2. (183-188).

Stocklmayer, S., Rayner, J. P. \& Gore, M. M. (2012). Changing the Order of Newton's Laws-Why \& How the Third Law Should be First. Physic Teacher, 50, 406-409.

Terzella, T. Sundermier, J. Sinacore, J., Owen, C. \& Takai, H. (2008). Measurement of $\mathrm{g}$ Using a Flashing LED. Physics Teacher, 46, 395-397.

Young, H.D. \& Freedman, R.A. (2007). University Physics with Modern Physics. London: Addison Wesley

Yuruk, N., Beeth, M. E. \& Andersen, C. (2009). Analyzing the Effect of Metaconceptual Teaching Practices on Students' Understanding of Force and Motion Concepts. Research in Science Education, 39(4), 449-477 